\title{
Cellulase Production Potentials of the Microbial Profile of Some Sugarcane Bagasse Dumping Sites in Ilorin, Nigeria
}

\author{
Kamoldeen A. AJIJOLAKEWU*, Alhasan SANI, Ganiyu P. OYEYIOLA, Risikat N. \\ AHMED, M.O. AREKEMASE, Mutiat B. ODEBISI-OMAKANYE, S.A. LABA \\ Department of Microbiology, University of Ilorin, Faculty of Science, Ilorin, Nigeria; ajijolakewu.ak@unilorin.edu.ng (*corresponding author)
}

\begin{abstract}
This research work investigated cellulase production potentials of the microbial profile of three sugarcane bagasse dumping sites at Zango area, Ilorin, Nigeria. The microbial isolates were screened for cellulase production with a view to select the best organism for eventual cellulase production. Pour Plate method was used for the isolation and a total of thirteen (13) different organisms including both fungal and bacterial species were isolated and screened. Six (6) fungal isolates identified as Mucor racemosus Aspergillus niger, Aspergillus flavus, Neurospora sitophilus, Penicillium oxalicum and Penicillium citrinum were isolated, while seven (7) different bacterial species isolated include Clostridium cellobioparum, Clostridium thermocellum, Bacillus subtilis, Bacillus pumillus, Lactobacillus spp, Pseudomonas flavescens and Serratia spp. Generally, bacterial isolates were more in abundance than fungal species. However; fungal isolates were constant and were isolated through the experimental period of three weeks. All the isolates showed cellulase production potential in varying degrees as reflected in the clearance zone around their colonies. Fungal isolates produced more cellulase than the bacterial isolates. Mucor racemosus had the highest clearance zone $(75.0 \mathrm{~mm})$ among the fungal isolates while Clostridium cellobioparum $(35.0 \mathrm{~mm})$ were the best producer among bacterial isolates. The least producer among fungal isolates, Penicillium citrinum ( $40.0 \mathrm{~mm})$, is a little more than the bacterial cellulase producer $(35.0 \mathrm{~mm})$ and is far greater than the least bacterium Serratia spp (14.0 mm).
\end{abstract}

Keywords: cellulase, dumping site, Ilorin, Mucor raceanosus, Serratia spp, Sugarcane bagasse and Zango

\section{Introduction}

Soil is an important reservoir for several industrially beneficial organisms (Willey et al., 2011). Soil organisms have been screened for the production of important products such as antibiotics (Ahmed et al., 2013), amylase producing organisms (Ajijolakewu and Sanni, 2012), cellulase producers (Chand et al., 2005; Bishnu et al., 2011) and a host of other beneficial products. Cellulases are enzymes which hydrolyze the $\beta$-1,4- glycosidic linkage of cellulose and synthesized by microorganisms during their growth on cellulosic materials. The complete enzymatic hydrolysis of cellulosic materials needs different types of cellulase; namely endoglucanase, (1,4-D-glucan-4-glucanohydrolase; EC 3.2.1.4), exocellobiohydrolase (1, 4-D-glucan glucohydrolase; EC 3.2.1.74) and glucosidase (D-glucoside glucohydrolase; EC 3.2.1.21) (Saranraj et al., 2012). Enzymatic process to hydrolyze cellulosic materials could be accomplished through a complex reaction of these various enzymes. Two significant attributes of these enzymebased bioconversion technologies are reaction conditions and the production cost of the related enzyme system. Therefore, there has been many research works focused on obtaining new microorganisms producing celluloytic enzymes with higher specific activities and greater efficiency (Saranraj et al., 2012).
Cellulose is considered to be the most abundant renewable polymer on earth. This structural material is naturally organized as microfibrils linked together to form cellulose fibers. It is biosynthesized by a number of living organisms ranging from higher to lower plants, some amoebae, sea animals, bacteria and fungi (Gilberto et al., 2010).

Cellulose rarely occurs freely in plant but in complex structure with hemicelluloses and lignin components to form lignocellulosic biomass. Hemicellulose is less complex, its concentration in lignocellulosic biomass is 25 to $35 \%$ and it is easily hydrolysable to fermentable sugars (Bishnu et al., 2011). Hemicellulose is a heteropoly saccharide composed of pentoses (D-xylose and $\mathrm{D}$-arabinose), hexoses (D-mannose, D-glucose and D-galactose) and sugar acids. Softwood hemicellulose mainly contains mannose as a major constituent whereas hardwoods mainly contain Xylans (Bishnu et al., 2011). Lignin is the third major component of lignocellulosic biomass and its concentration ranges from 20 to $35 \%$. It is a complex polymer of phenyl propane ( $\mathrm{p}$-coumaryl, coniferyl and sinapyl alcohol). Lignin acts as cementing agent and an impermeable barrier for enzymatic attack (Bishnu et al., 2011). Lignin provides plants with the structural support and impermeability they need as well as resistance against microbial attack and oxidative stress. These properties of lignin may be attributed to its amorphous nature, water insolubility and 
446

optical inactivity. The latter properties also make it tough to degrade (Bishnu et al., 2011).

Sugarcane bagasse, an example of lignocellulosic materials, has not been harnessed for its potential energy value in Nigeria. Bagasse is a residue obtained from sugarcane after it is crushed to obtain the juice used for sugar and ethanol production. Sugarcane bagasse (SUGARCANE BAGASSE) contains appreciable amount of cellulose and hemicellulose, which can be depolymerized by chemical or enzyme cocktails into simple sugar monomers (glucose, xylose, arabinose, mannose, galactose, etc.) (Chandel et al., 2012). Such sugar streams obtained from Sugarcane bagasse and Sugarcane leave can be converted into bioethanol and value-added products of commercial significance, which has joint economic importance (Chandel et al., 2012). The dumping of sugarcane bagasse as a waste despite its high cellulosic component provided the basis of this work.

Both fungi and bacteria have been largelyexploited for their abilities to produce wide varieties of cellulases and hemicellulases. A lot of emphasis has been placed on the use of fungi, because of their ability to produce copious amount of cellulases and hemicellulases which are secreted into the broth culture for easy extraction and purification. Besides, the fungal enzymes are often less complex than bacterial hydrolases and can therefore be readily cloned and recombined in a more rapidly growing host such as $E$. coli (Maki et al., 2009).

This research is aimed at (i) investigating the microbial community of the acidic soil sample from sugarcane bagasse dumping site and (ii) screening the isolated microoganisms for cellulase production

\section{Materials and methods}

Collection of soil samples

Soil samples were collected from three different sugarcane bagasse dumping sites labelled A, B and C at Zango area, Ilorin, Kwara State for the period of three weeks. With a sterile hand trowel, soil samples were collected from the top of the soil up to $20 \mathrm{~cm}$ depth (Okoth et al., 2007) in a black polythene bag. The temperatures of the soil at the points of collection were recorded and the samples were immediately transferred in an ice chest to the laboratory for analysis. Samples were collected in March, 2013.

\section{Isolation and maintenance of cellulase producing organisms}

One gram of each soil samples (sieved through a $2 \mathrm{~mm}$ sieve) collected as above was mixed with $10 \mathrm{ml}$ of $0.1 \%$ $(\mathrm{w} / \mathrm{v})$ peptone water in a test tube by vortex to break clumps. This mixture was shaken vigorously and used for the isolations in a modified Mandels (Chand et al., 2005) medium.

Bacteria. One millilitre of the suspension from the interface of the column of sedimented material and super- natant fluid was serially diluted from $10^{-1}$ to $10^{-6}$, and 0.1 $\mathrm{ml}$ each of the appropriate dilutions was plated on modified Mandels' medium (NA-CMC-Mandels medium) consisting of (g/l): 28 N.A, 2 CMC, $2.0 \mathrm{KH}_{2} \mathrm{PO}_{4}, 1.4$ $\left(\mathrm{NH}_{4}\right)_{2} \mathrm{SO}_{4}, 0.3$ Urea, $0.3 \mathrm{MgSO}_{4}, 0.3 \mathrm{CaCl}_{2} .2 \mathrm{H}_{2} 0,1.0$ PEPTONE, $0.5 \mathrm{FeSO}_{4} .7 \mathrm{H}_{2} \mathrm{O}, 0.16 \mathrm{MNSO}_{4} .2 \mathrm{H}_{2} \mathrm{O}, 0.14$ $\mathrm{ZNSO}_{4} .7 \mathrm{H}_{2} \mathrm{O}, 0.2 \mathrm{CoCl}_{2} .2 \mathrm{H}_{2} \mathrm{O}$ by pour plate method. Two percent Nistatin was added to prevent fungal growth. The agar plates were incubated at $37{ }^{\circ} \mathrm{C}$ for $24 \mathrm{hrs}$ Pure isolates were maintained on an agar slant at $4{ }^{\circ} \mathrm{C}$ until needed for use.

Fungi. Supernatant fluid was serially diluted to $10^{-3}$, and $0.1 \mathrm{ml}$ of the dilution was plateded on modified PDACMC-Mandels' medium. Two percent penstrept (penicillin-streptomycin combination) antibrotics was added to prevent bacterial growth. The agar plates were incubated at $27^{\circ} \mathrm{C}$ for $72 \mathrm{hrs}$. Pure isolates were maintained on an agar slant at $4{ }^{\circ} \mathrm{C}$ until needed for use.

\section{Microbial 2uality of S.B Dumping Sites}

Three different locations (A, B and C) were screened for the presence or absence of each member of isolated microbial population by respectively and independently subjecting each soil sample from these sites to microbial analysis.

\section{Sreening for Cellulase Production}

The primary criterion for the selection of cellulase producing microbial isolates was the formation of clear zone around a microbial colony in a PDA or NA-CMCMandels medium respectively for both fungal and bacterial isolates after each medium was flooded with $1 \%$ congo red solution.

Bacterial isolates were individually streaked on NACMC-Mandels medium. After incubation for $48 \mathrm{hrs}$, the plates were flooded with $1 \%$ congo red and allowed to stand for 15 mins at room temperature. One molar $\mathrm{NaCl}$ was thoroughly used to counterstaining the plates. Clear zones which appear around growing bacterial colonies indicated cellulose hydrolysis. Average diameter of the clear zones was recorded and compared (Andro et al., 1984).

Spore suspensions of each fungal isolates were harvested by washing their respective 48 hrs old cultures with 10 $\mathrm{ml}$ sterile distilled water. One millilitre $(1 \mathrm{ml})$ each of the fungal spores, made up to $8 \times 10^{5}$ spores per $\mathrm{ml}$ after observation in hemocytometre, was inoculated unto PDACMC Minimal medium supplemented with 2\% streptomycin. After incubation for $48 \mathrm{hrs}$, the plates were flooded with $1 \%$ congo red and allowed to stand for 15 mins at room temperature. One molar $\mathrm{NaCl}$ was thoroughly used to counterstaining. Clear zones which appear around growing bacterial colonies indicated cellulose hydrolysis. Average diameter of the clear zones were recorded and compared (Mandels and Weber, 1969 as adapted from Chand et al., 2005). 


\section{Identification}

Characterization and identification of bacterial isolates

The characterization and identification of bacterial isolates were based on colonial, cellular morphology and biochemical tests. Identification was based on Bergey's manual of Determinative Bacteriology (Buchanon and Gibbon, 1974) and Practical Atlas for Bacterial Identification (Cullimore, 2000).

\section{Identification of fungal isolates}

Identification of fungal isolates was based on their growth pattern, colonial morphology and the structure and colour of spores and reference were made to appropriate mycology texts including Onions et al. (1981) and Pitt and Hocking (1985).

\section{Results}

Microbial profile of soil samples collected from Sugarcane bagasse dumping sites

Tab. 1 and 2 show the microbial profile of soil samples collected from different sugarcane bagasse dumping sites, Zango Area, Ilorin. Six fungal and seven bacterial species were isolated. Fungal species were identified as Mucor racemosus, Aspergillus niger, Neurospora sitophilus, Aspergillus flavus, Penicillium oxalicum and Penicillium citrinum, while bacterial isolates were identified as Bacillus pumillus, Pseudomonas flavescens, Bacillus subtilis, Clostridium thermocellum, Clostridium cellobioparum, Lactobacillus spp and Serratia spp.

Tab. 1. Bacterial profile of Sugarcane Bagasse dumping sites

\begin{tabular}{cccc}
\hline \multirow{3}{*}{ Week } & \multicolumn{4}{c}{ Sites of collection/counts } \\
& $\mathrm{A}(\mathrm{cfu} / \mathrm{ml})$ & $\mathrm{B}(\mathrm{cfu} / \mathrm{ml})$ & $\mathrm{C}(\mathrm{cfu} / \mathrm{ml})$ \\
1 & $6.2 \times 106$ & $3.7 \times 104$ & $9.8 \times 106$ \\
2 & $3.1 \times 106$ & $3.2 \times 104$ & $6.2 \times 106$ \\
\hline 3 & $3.0 \times 106$ & $3.0 \times 104$ & $6.0 \times 106$ \\
\hline
\end{tabular}

$\mathrm{pH}=3.4$

The microbial counts of the soil samples was highest in the first week of sampling with site $\mathrm{C}$ having the highest count for both the bacteria $\left(9.8 \times 10^{6} \mathrm{cfu} / \mathrm{ml}\right)$ and fungi $\left(5.2 \times 10^{3} \mathrm{cfu} / \mathrm{ml}\right)$ while site $\mathrm{B}$ had the least microbial counts during the three weeks experimental period.

Tab. 3 shows microbial quality of the bagasse dumping site. At the first experimental week, all isolates were present at all sampling sites. By the second and third weeks most of the bacterial isolates and some fungal isolates were randomly present or absent especially at site B. Both Pseudomonas flavescens and Serratia spp were however completely absent at the third week of the experiment.
Tab. 2. Fungal profile of Sugarcane Bagasse dumping site

\begin{tabular}{cccc}
\hline \multirow{3}{*}{ Week } & \multicolumn{3}{c}{ Sites of collection/counts } \\
& $\mathrm{A}(\mathrm{cfu} / \mathrm{ml})$ & $\mathrm{B}(\mathrm{cfu} / \mathrm{ml})$ & $\mathrm{C}(\mathrm{cfu} / \mathrm{ml})$ \\
1 & $5.4 \times 103$ & $4.9 \times 102$ & $5.2 \times 103$ \\
2 & $3.4 \times 103$ & $3.0 \times 102$ & $3.1 \times 103$ \\
3 & $3.1 \times 103$ & $3.0 \times 106$ & $3.4 \times 103$ \\
\hline
\end{tabular}

$\mathrm{pH}=3.4$

Tab. 3. Microbial Quality of Sugarcane Bagasse Dumping Site $(\mathrm{cfu} / \mathrm{ml})$

\begin{tabular}{|c|c|c|c|c|c|c|c|c|c|}
\hline \multirow{2}{*}{ Microorganism } & \multicolumn{3}{|c|}{ WK 1} & \multicolumn{3}{|c|}{ WK 2} & \multicolumn{3}{|c|}{ WK 3} \\
\hline & A & B & $\mathrm{C}$ & A & $\mathrm{B}$ & $\mathrm{C}$ & A & B & C \\
\hline $\begin{array}{l}\text { Clostridium } \\
\text { cellobioparum }\end{array}$ & + & + & + & + & + & + & + & + & + \\
\hline $\begin{array}{l}\text { Clostridium } \\
\text { thermocellum }\end{array}$ & + & + & + & + & - & + & - & - & + \\
\hline Bacillus subtilis & + & + & + & + & - & + & - & + & + \\
\hline Bacillus pumillus & + & + & + & - & + & + & - & - & + \\
\hline Lactobacillus spp & + & + & + & - & - & + & - & - & + \\
\hline $\begin{array}{c}\text { Pseudomonas } \\
\text { flavescens }\end{array}$ & + & + & + & - & - & + & - & - & - \\
\hline Serratia spp & + & + & + & - & - & + & - & - & - \\
\hline Mucor racemosus & + & + & + & + & + & + & + & + & + \\
\hline Aspergillus niger & + & + & + & + & + & + & + & + & + \\
\hline $\begin{array}{l}\text { Neurospora } \\
\text { sitophilus }\end{array}$ & + & + & + & + & + & + & - & + & + \\
\hline Aspergillus flavus & + & + & + & + & + & + & + & + & + \\
\hline $\begin{array}{l}\text { Penicillium } \\
\text { oxalicum }\end{array}$ & + & + & + & + & - & + & + & - & + \\
\hline $\begin{array}{l}\text { Penicillium } \\
\text { citrinum }\end{array}$ & + & + & + & + & + & - & + & - & + \\
\hline
\end{tabular}

$\mathrm{KEY}+=$ Present $-=$ Absent $\mathrm{pH}=3$

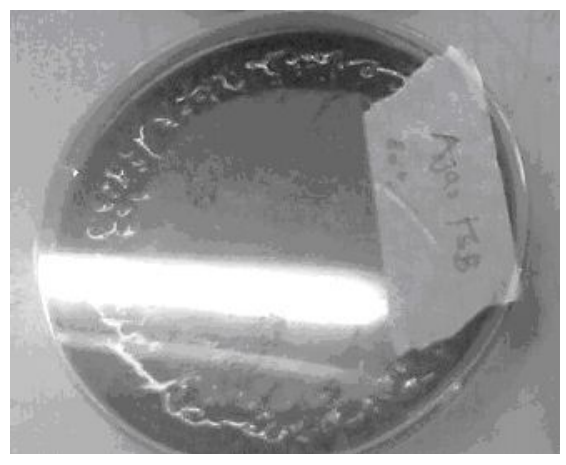

Fig. 1. Clearance zone around a fungal colony after staining

\section{Screening for cellulase production}

Tab. 4 shows the screening result for cellulase production. All the isolates showed cellulase production poten- 
448

tial but in varying degrees. Fungal isolates generally produced more celllulase than bacteria. Mucor racemosus had the highest clearance zone $(75.0 \mathrm{~mm})$ among the fungal isolates, while Clostridium cellobioparum $(35.0 \mathrm{~mm})$ had the highest among bacterial isolates. Penicillium citrinum which had the least zone $(40.0 \mathrm{~mm})$ is far better than the least bacterium Serratia spp $(14.0 \mathrm{~mm})$ and a little more than the best bacterial cellulase producer. Fig. 1 shows clearance zone around fungal colony after staining with $1 \%$ iodine solution.

Tab. 4. Screening for cellulase production

\begin{tabular}{|cc|}
\hline Organisms & Zone of clearance $(\mathrm{mm})^{*}$ \\
\hline Clostridium cellobioparum & 35.0 \\
\hline Bacillus subtilis & 30.0 \\
\hline Clostridium thermocellum & 26.0 \\
\hline Bacillus pumillus & 24.0 \\
\hline Lactobacillus spp & 20.0 \\
\hline Pseudomonas flavescens & 20.0 \\
\hline Serratia spp & 14.0 \\
\hline Mucor racemosus & 75.0 \\
\hline Aspergillus niger & 60.0 \\
\hline Aspergillus flavus & 60.0 \\
\hline Neurospora sitophilus & 55.0 \\
\hline Penicillium oxalicum & 50.0 \\
\hline Penicillium citrinum & 40.0 \\
\hline
\end{tabular}

Temp: $+320 \mathrm{C} \pm 1$ Inoculum size (fungal isolates): 8 x 105 sporeml-1.

${ }^{*}=$ Values are expressed as means of three independent readings

\section{Discussion}

This works investigated the microbial profile of the soil samples from sugarcane bagasse processing site at Zango Ilorin. The isolates were screened for their cellulase production potential with a view to selecting organisms having highest potential for cellulase production. A total of thirteen (13) different organisms including both fungal and bacterial species were isolated and screened. Six (6) fungal isolates identified as Mucor racemosus, Aspergillus niger, Aspergillus flavus, Neurospora sitophilus, Penicillium oxalicum and Penicillium citrinum were isolated, while seven (7) different bacterial species isolated include Clostridium cellobioparum, Clostridium thermocellum, Bacillus subtilis, Bacillus pumillus, Lactobacillus spp, Pseudomonas flavescens and Serratia spp. Similar isolations have been made (Otajevwo and Aluyi, 2011; Bishnu et al.,2011). Some of these organisms were not seen at some time during the experiment. This suggests that they might have been affected by environmental factors, mainly water activity. Environmental factors which affect growth of organisms have been discussed (AgriInfo, 2011). Water is needed to dilute the soil's high acidity ( $\mathrm{pH} 3.4$ ) and therefore as shown in Tab. $1-3$, the rainfall which characterised only the first sam- pling week ( $1^{\text {st }}$ week of March, 2013) might have raised the humidity and the water activity of the soil, hence the high microbial count and quality observed in the first week. Similar organisms have been isolated from different soil samples including rice-straw, cassava and yam peels dumping sites (Saranraj et al., 2012). The presence and abundance of all the isolates at site C (Tab. 1-3) could be due to high concentration of lignocellulosic bagasse which prevents competition as oppose to site B where some species takes competitive advantage due to limiting nutrient over others. Generally, bacterial isolates outnumbers fungal species in all the sites investigated. Bacteria species have been shown to be more abundant in the soil and in varieties of environment and industrial niches (Otajevwo and Aluyi, 2011; Maki et al., 2009). However, fungal isolates are stable and were isolated all through the experimental period of three weeks. This further confirms that fungi can withstand harsh conditions (Willey et al., 2011).

As shown in Tab. 3, all the microbial isolates produce cellulases. Mucor racemosus had the highest clearance zone $(75.0 \mathrm{~mm})$ among the fungal isolates while Clostridium cellobioparum $(35.0 \mathrm{~mm})$ had the highest among bacterial isolates. Generally, fungal isolates produced more cellulases than all bacterial isolates. In fact, the least producer among fungal isolates, Penicillium citrinum ( 40.0 $\mathrm{mm}$ ) (Tab. 4) produced more cellulases than the highest producer among the bacterial isolates, Clostridium cellobioparum $(35.0 \mathrm{~mm})$ and this is far better than the least bacterium Serratia spp $(14.0 \mathrm{~mm})$. Similar observation was made by Maki et al., (2009). This disparity could be due to the ability of the fungal species to adapt to and survive in harsh conditions which are characteristics of the lignocellulosic waste dumping sites. This agrees with findings by Ajijolakewu and Sani (2012); Ray (2004) and Uguru et al. (1997).

\section{Conclusion}

This work has demonstrated that soil is a very rich source of cellulolytic organisms. Fungal isolates especially Mucor racemosus and Aspergillus niger have been found to be potential and viable cellulase producers. Works are still on to produce cellulase using these organisms and to determine the various culture conditions such as substrate concentrations, temperature, incubation period, $\mathrm{pH}$ etc. that favours cellulase production by these organisms. Also there is an ongoing work to determine the properties of cellulases produced by these organisms. Bacterial isolates including, but not limited to, Clostridium cellobioparum and Bacillus subtilis will also be improved upon through optimisation of cultural conditions and genetic enhancement for better cellulase production. 


\section{References}

AgriInfo (2011). Factors affecting distribution, activity and population of soil microorganisms. http://agriinfo.in/?page $=$ to pic\&superid $=5 \&$ topicid $=152$. Assessed on 30/05/2013.

Ahmed RN, Sani A, Ajijolakewu AK, Alamu FB (2013). Soil screening for antibiotic-producing microrgansms. Adv Environ Biol 71:7-11.

Ajijolakewu AK, Sani A (2012). Amylase production by Penicillium chrysogenum in a submerged fermentation of cassava powder. Proc $25^{\text {th }}$ Annual Conference of Biotechnology Society of Nigeria. p. 161-167.

Andro T, Chambost JP, Kotoujansky A, Cattano J, Barras F (1984). Mutants of Erwinia chrysanthemi defective in secretion of pectinase and cellulase. J Bacteriol 160(3):11991203.

Bishnu J, Megh R B, Dinita S, Jarina J, Rajani M, Lakshmaiah $S$ (2011).Lignocellulosic ethanol production: Current practices and recent developments Biotechnology and Molecular Biology Review 68:172-182.

Buchanan ER, Gibbons N. E. (1974). Bergey's Manual of Determinative Bacteriology. $8^{\text {th }}$ Edition. The Williams and Wilkins Co., Baltimore. 8: 6-13.

Chand P, Aruna A, Maqsood AM, Rao LV (2005). Novel mutation method for increased cellulase production. Journal of Applied Microbiology 98:318-323.

Chandel A K, Silvio S, Walter C and Om VS (2012). Sugarcane bagasse and leaves: foreseeable biomass of biofuel and bioproducts. J Chem Technol Biotechnol 87:11-20.

Cullimore DR (2000). Practical Atlas for Bacterial Identification. Lewis Publishers, Boca Raton, London, New York, p 209.

Gilberto S., Julien B., Alain D. (2010) Cellulosic Bionanocomposites: A review of preparation, properties and applications. Polymers 2(4):728-765.
449

Maki M, Leung KT, Quin W (2009). The prospect of cellulose producing bacteria for bioconversion of lignocellulosic biomass. J Bio Sci 5:500-516.

Mandels M, Weber J.(1969) Production of cellulases. Advances in Chemistry Series 95:391-414.

Okoth SA, Rolmen H, Mutsotso B, Owino JO (2007). Land use system and distribution of Trichoderma species in Embu Region, Kenya. J of Tropical and Subtropical Agrosystems 7:105-122.

Onions AHS, Allsopp D, Eggims HOW (1981). Introduction to Industrial Mycology 7 th edition. Edward Arnold Publishing Company Limited, p 27-30.

Otajevwo FD, Aluyi HSA (2011). Cultural conditions necessary for optimal cellulase yield by cellulolytic bacterial organisms as they relate to residual sugars released in broth medium. Modern Applied Sci 5(3):141-151.

Pitt JL , Hocking AD (1985). Fungi and Food Spoilage. CSIRO Division of Food Research, Academic Press Sydney.

Saranraj P, Stella D, Reetha D (2012). Microbial cellulases and its applictions: a review. International $\mathrm{J}$ of Bioche $\&$ Biotech Sci 1:1-12.

Ray RC (2004). Extracellular amylases production by fungi Botryodiplodia theobromae and Rhizopus oryzae grown on cassava residue. J Environ Bio 25:489-495.

Uguru GC, Akinyanju JA, Sani A (1997). The use of surghum for thermostable amylase production from Thermoactinomyces thalpophius. Letters in Applied Microbiology 25:13-16.

Willey JM, Sherwood LM, Woolverton CJ (2011). Microorganisms in terrestrial environment. Prescott, Harley and Klien's Microbiology. Mc Graw-Hill International Eight. edition. New York. 693-698. 